\title{
MOBILE LEARNING IN DEVELOPING PHONETIC COMPETENCE OF FUTURE INTERPRETERS
}

\author{
Tetiana Gurova, Tetiana Riabukha, Natalia Zinenko, Natalia Gostishcheva \\ Bohdan Khmelnitsky Melitopol State Pedagogical University \\ tatianagurova2017@gmail.com
}

\begin{abstract}
The article considers teaching English phonetics to future interpreters with mobile learning in the light of the competence approach. The authors analyse the possibilities of applying mobile learning as an additional source and demonstrates the feasibility of its implementation in teaching English phonetics. The primary aim of this research is to examine the effectiveness of m-learning on the development of future interpreters' English phonetic competence. Such activities used in mobile learning as "Group Mind Mapping of Key Phonetic Issues", "Creating Event-Glide Calendar as a Guide of a Coursework", "E-Presentations on Teaching and Learning Phonetics", "Real-Time Testing", "Public Pronunciation Assessment", "Different Perception" are described and analysed. During the pedagogical experiment, the criteria (cognitive; pragmatic; reflective), indicators, and levels (high, average and low) of the formation of future interpreters' English phonetic competence through mobile learning were determined. 50 students of the Faculty of English philology and methodology of teaching English at Bohdan Khmelnytsky Melitopol State Pedagogical University took part in the experiment. The results prove that applying mobile learning in teaching English phonetics provides an opportunity to increase the level of English phonetic competence of future interpreters as well as encourages them for self-development and creative work.
\end{abstract}

Keywords: phonetic competence; mobile learning technologies; English pronunciation; future interpreters.

\section{Introduction}

Rapid development of information technologies has encouraged the changes in the system of education in general and the search for more appropriate and effective strategies for training future interpreters in particular. Expanding opportunities to reflect knowledge in the form of a hypertext, a significant reduction in the cost of gadgets have contributed to the use of digital media in English classes in the higher school. As Bates (2010) noticed, the introduction of technology into teaching, learning, and research makes the necessity of change apparent, it is neither the only reason nor the only area in which universities will have to adopt new organisational models. Thus, in English classrooms, there appeared IT-technologies, providing additional opportunities for students to improve their language skills.

The changed education paradigm for the transition from studying for the rest of life into lifelong learning determines the radical shift of goals, content, forms and means of English teaching methodology. Moreover, the market economy and the globalisation of communication have generated a lot of political, economic, technological, scientific and cultural exchange which is often mediated by translators and interpreters. Therefore, the need for well-trained specialists who are able to convey a message effectively, be it written or spoken, from one language to another has also arisen.

Indisputable is the fact that the linguistic component of translator's/interpreter's competence implies a good knowledge of both the source and the target language. As Cherednychenko (2007) claims, excellent knowledge of two languages facilitates the ability to switch from one language to another in written and oral form. Furthermore, according to the author's opinion, linguistic competence develops linguistic skills which allow to avoid the native (the source) language interference while translating into the foreign (the target) one (Cherednychenko, 2007, p. 233). Being an interpreter requires high intelligibility of a foreign language in order to fulfil the task of communicating a message properly. The usual working environment would include the situations when you cannot ask for repetition or clarification of the information you hear (Zapolskykh, 2017). Consequently, students obtaining this speciality should also aim at developing both their productive and, even more important, receptive skills in language learning. Most scholars in the field, Kenworthy (1987) and language as well as awareness of the processes in connected speech help learners to improve the ability to listen actively and produce accurate and correct speech, i.e. enhance intelligibility of the language they are learning. In other words, they are writing about phonetic competence, which is part and parcel of a person's communicative competence.

In the European Reference Framework (2011) one may find the notion of phonetic competence, which includes knowledge and skills of sound perception and production. However, this definition doesn't take into account the ability of an individual to accomplish speech activity based on his/her existing knowledge, skills and abilities that are the main features of any competence. Such definition, in our opinion, can be considered

Gurova, T., Riabukha,T. Zinenko,N., \& Gostishcheva, N. (2020). Mobile learning in developing phonetic competence of future interpreters. Advanced Education, 14, 66-74. https://doi.org/10.20535/2410-8286.155398 
as a false one, because it generates isolation of the form from its content, which consequently condemns phoneticians' work to failure when students start real communication in English. The researches in phonetics done by Khomutova (2013) and developed by Goncharova (2006) give a detailed description of the structure and content of phonetic competence.

Based on their definitions and considering the above points of view let us define the notion of phonetic competence. Hence, under the foreign language phonetic competence, we understand the system which contains the following components: knowledge about the normative composition of pronounced elements (phonemes and intonation patterns) of a foreign language; listening and pronunciation; rhythmic and intonation skills to automate their selection and combine them; phonetic skills. We define phonetic competence as the phonetic organisation of speech that basically determines the success or failure of verbal interaction in the context of intercultural communication (Riabukha et al., 2018). Thus, developing future interpreters' phonetic competence is ultimately significant for them to achieve real-life communicative aims such as conveying a message, when signalling interrupting, asking somebody for clarification, changing the subject or concluding an argument. An ideal interpreter understands everyone and is understood by everyone. On the perception side, this means that interpreters can cope with the enormous variability in pronunciations they encounter. For their own speech production, then, this means not being marked by noticeable regional or foreign features. Accent contributes a great deal to how a speaker is perceived, and a strong foreign accent may draw attention away from what is being said as well as generate attitudinal reactions on the part of the listeners. Good interpreters do not draw attention to themselves.

In recent years, the issue of the use of innovative technologies at universities has become popular. This is not only new technical means, but also new forms and methods of teaching, new approaches to the learning process as well. E-learning, blended learning, and mobile learning offer a new universe of interactivity for learning purposes (Bartolomé-Pina et al., 2018). Nowadays learning English with mobile devices is gradually increasing, the raise of their popularity in studying coincided with rapidly diminishing cost of tablet devices, which, in its turn, reinforced a new format of English classes. Learning based on electronics nowadays can be viewed equally as the cause and the consequence of relevant changes in the concept of education, as well as the ways of how it should be implied (Abazi-Bexheti et al., 2018). Thus, as technologies began to change the way English learnt and taught in the classroom, even bigger changes seem to be taking place outside it. In fact, the digital revolution in learning now threatens to undermine the classroom completely as a place of study.

Mobile technologies are becoming more embedded, ubiquitous and networked, with enhanced capabilities for rich social interactions, context awareness and internet connectivity. Such technologies can have a great impact on learning. They allege that learning will gradually move outside of the classroom and into the learner's environments, both real and virtual, thus becoming more situated, personal, collaborative and lifelong. The main challenge to teachers will be to discover how to use mobile technologies to transform learning into a seamless part of daily life to the point where it is not recognised as learning at all (Naismith et al., 2004; Pegrum, 2014). Consequently, choosing a new technology to work with, a teacher should keep in mind the balance maintaining between traditional methods and innovative ones.

Nowadays mobile learning is considered to be a new stage of distance and e-learning. There are several definitions and interpretations of the concept of "m-learning" in the scientific literature at the moment; they are based either on technological features or on didactic capabilities of these devices. To define a concept of m-learning we should note that according to Taylor (2006) there are commonly three main schools of thought on what means mobile learning: learning mediated by mobile devices, mobility of learners (regardless of their devices) and mobility of content/resources meaning it can be accessed from anywhere. Kekwaletswe (2007) states that mobile learning may be defined as any sort of learning and knowledge sharing that may happen due to social awareness when the learner is not at fixed or predetermined conditions. Sharples (2006) confirms m-learning is characterised by the following features: it enables knowledge building by learners in different contexts; enables learners to construct understandings; mobile technology often changes the pattern of learning/work activity; the context of m-learning is about more than time and space. In this paper, personalised m-learning is signified by interactions of future interpreters while studying the course of Practical phonetics within the English phonetics classes, using Web 2.0 tools and electronic thoroughly selected electronic recourses. In the literature on the problem, there are different definitions for m-learning, some scientists consider it only as wireless or Internet based.

In our opinion, the definition of m-learning should include the ability to learn everywhere at every time without a permanent physical connection to cable networks. Therefore, within our research, we understand $\mathrm{m}$-learning as the process of using portable, wireless, convenient and accessible mobile devices in education, 
in order to optimise and support learning phonetics that will allow the learner to communicate, create or receive the necessary information, drill phonetic elements and achieve more profound academic success.

The introduction of such type of e-learning as m-learning into the system of English phonetics classes raises a number of issues for scientists and practitioners. First, we should consider what includes the content of the concept of "m-learning" in teaching English phonetics; second, it is necessary to investigate what changes should be introduced in all components and levels of the system of teaching phonetics (theoretical and methodological foundations, goals, content, tools, methods, technologies, forms and types of educational activities; third, to identify didactic functions, properties of mobile devices and conditions of their involvement in the learning process.

It is noteworthy that m-learning is not the process of transferring educational materials to a small screen and the use of mobile devices, but the development of innovative educational mobile materials that will be mastered through the introduction of innovative forms of learning: educational microblogs, news feeds, interactive course casts, etc. Thus, extensive technical capabilities of mobile devices allow access to the global network, visiting the necessary sites, e-mail exchange, sending the necessary electronic files, organising testing on mobile devices, self-control of future interpreters' academic performance, their knowledge of the subject, access to electronic textbooks, playback of audio, graphic and video files, which allow improving the quality of pronunciation.

The aim of this research is to substantiate the potential and effectiveness of using mobile device educational technology in forming phonetic competence of future interpreters and to show the ways of applying m-learning as an additional source of teaching practical phonetics. The hypothesis of the study is that the effectiveness of future interpreters' professional training increases if the formation of phonetic competence is carried out with the use of m-learning in teaching English phonetics.

\section{Methods}

In our research the following methods were used: theoretical methods: a systematic and comparative analysis of psychological and pedagogical, methodical and scientific literature on the research issues; an analysis of existing teaching materials used to train future interpreters (curriculum, plans, tutorials, textbooks, audio- and video materials, etc); interdisciplinary synthesis; systematisation of theoretical data, etc; generalisation of pedagogical experience for making conclusions and recommendations for the efficient developing of phonetic competence of future interpreters, etc.; b) empirical methods: tests, questionnaires, interviews, participant observation in the educational process.

Participants. The research was held on the basis of the Bohdan Khmelnitsky Melitopol State Pedagogical University and enrolled 50 undergraduate students majoring in "Interpreters".

Materials. To conduct the experiment, the course "Practical Phonetics" provided with electronic resources for mobile learning (audio files for training pronunciation) and a tutorial "Speech Without a Hitch, or Practice Makes Perfect" were prepared. The course was designed mainly for classroom work (seminars) and for individual work at home. Students of the control group used only the tutorial and handouts at the lessons while the students from the experimental group were also provided with carefully selected electronic resources and Web 2.0 technologies for using with the help of mobile devices at the lessons and at home. The EG Students used materials in the form of presentations, video files on topics, text documents, links with tips and drills for pronunciation mastering as well as options for homework assignments, tests, questionnaires, and various references. To discuss the issues, a chat room was created which allowed adding comments and useful links.

Procedure. The pedagogical experiment was conducted in two stages. At the first stage we aimed at determining the state of the future interpreters' phonetic competence by using tests, questionnaires and interviews as well as analysing documentation, teaching materials and methods, considering the results of final tests, credits, examinations, self-study of future interpreters. The analysis of the results showed insufficient phonetic competence of the first-year students after school; insufficient knowledge of phonetic terms; lack of phonetic skills; a small amount of hours for classroom work; students' inability to organise their self-study appropriately by distributing time and efforts for preparation; lack of motivation; the prevalence of reproductive work; lack of using e-learning in the subject.

At the second stage of our experiment, two groups were formed: an experimental group (EG) included 23 first-year students and a control group (CG) included 27 majoring in "Interpreters" who study full-time. The CG students were taught using traditional teaching methods. Other conditions for both groups were approximately the same: the English level; the number of students in the groups; the higher educational institution; topics of the syllabus and hours for classroom study and self-study. 
Based on the studies of phonetic competence structure we developed the criteria, indicators, and levels of the formation of future interpreters' phonetic competence during the pedagogical experiment (Khomutova, 2013). Table 1 presents the criteria and indicators of formation of students' phonetic competence.

Table 1. The criteria and indicators of formation of future interpreters' phonetic competence with the use of m-learning

\begin{tabular}{|c|c|c|}
\hline Cognitive & Pragmatic & Reflective \\
\hline $\begin{array}{l}\text { knowledge of the system vowels } \\
\text { and consonants and their } \\
\text { modification; } \\
\text { knowledge of syllabical structure } \\
\text { and stress manifestation in } \\
\text { English words; } \\
\text { knowledge of intonation patterns. }\end{array}$ & $\begin{array}{l}\text { skills of differentiating of similar } \\
\text { sounds; } \\
\text { ability to pronounce correctly } \\
\text { English vowels and consonants; } \\
\text { applying knowledge of sound } \\
\text { modification and intonation } \\
\text { patterns in speech. }\end{array}$ & $\begin{array}{l}\text { ability to estimate one's } \\
\text { pronunciation; } \\
\text { finding the correspondence } \\
\text { between the final result of } \\
\text { pronunciation and the given } \\
\text { patterns; } \\
\text { correction of own pronunciation } \\
\text { on the basis of self-assessment }\end{array}$ \\
\hline
\end{tabular}

We started the experiment with a pre-study questionnaire which included items related to information about the students' knowledge of pronunciation aspects, self- assessment of their pronunciation and problems they have with it. This instrument was distributed to all students at the beginning of the academic year. Quantitative and qualitative indicators derived from the results of the preliminary stage of the experiment led to the conclusion that the level of phonetic competence in both groups is homogeneous.

In order to check the levels of the three criteria the cognitive criterion, the pragmatic and the reflective one of the formation of phonetic competence, we used a diagnostic test where students had to do tasks on recognition, choice and use of sounds, stress patterns and intonation groups. When compiling the test, we proceeded from the fact that the phonetic test should control both speech perception skills and speech production skills, since their interaction provides the phonetic design of speech. The test material should be related to the objects of assessment.

Test Types and Assessment Objects in a Phonetic Test

\begin{tabular}{|c|c|c|c|}
\hline \multicolumn{2}{|c|}{ Test Types } & $\begin{array}{c}\text { Testing } \\
\text { Speech Perception } \\
\text { (Listening) }\end{array}$ & $\begin{array}{c}\text { Testing } \\
\text { Speech Production } \\
\text { (Reading Aloud)) }\end{array}$ \\
\hline \multirow{2}{*}{$\begin{array}{c}\text { Assessment Objects } \\
\text { segmental } \\
\text { units }\end{array}$} & vowels & + & + \\
\cline { 2 - 4 } $\begin{array}{c}\text { suprasegmental } \\
\text { units }\end{array}$ & consonants & + & + \\
\cline { 2 - 4 } & word stress & + & + \\
\cline { 2 - 4 } & intonation (tones) & + & + \\
\hline
\end{tabular}

The phonetic test that we prepared and used consisted of two parts - perception (Listening) and production (Reading Aloud). They included discrete items, although the sequence of tasks was determined by the hierarchical structure of the phonetic system of the language: segment level units $\rightarrow$ suprasegment level units, i.e. from the sound in syllables (words) to the intonation component of statements (text). Here are examples of discrete items: (1) First listen to the whole line. Then underline the word that is said twice; (2) Listen to the dialogue and underline the words that are stressed by the speakers. As for testing technique, multiple choice was used to test speech perception, and video recording to test speech production. Processing of the test results and their evaluation was done as follows. In the perception tests, every correct answer was estimated at 1 mark, and every incorrect answer was estimated at 0 marks. The videos of production tests were analysed by the testers, and the results of the test were recorded in the registration matrix. Each controlled intonation unit was estimated at 1 point (if correct), and 0 (if incorrect). In addition, the marks were reduced in the following cases: at 0.2 for each phonological mistake at the segmental level, and at 0.1 for each allophonic variation mistake at the segmental level; for any violation of the accentual-rhythmic structure, 0.1 marks were also removed. Then, we used the formula suggested by B. P. Bezpalko: $K=Q / N$, 
where $\mathrm{K}$ is the index of skill development, $\mathrm{Q}$ - number of correct answers, and $\mathrm{N}$ - maximum possible number of correct answers.

The results of all the subtests were subjected to quantitative analysis. To define students' indices of the development of separate phonetic competence components we divided the number of correct answers in each subtest by the number of maximum correct answers which could possibly be given in this part of the test and calculated the arithmetic mean of the results of all the subtests aimed at assessing some definite component. The general level of students' professional phonetic competence was equal to the arithmetic mean of the indices, received for all the objects of the assessment.

We differentiated between four levels of phonetic competence development: initial, medium, sufficient and high. The index lower than 0.6 was considered to be initial. According to the 100-point grading scale, it is equal to 1-59 points and traditionally corresponds to the "unsatisfactory" grade in Ukrainian universities. The index between 0.6 and 0.73 presented the medium level. It equates to $60-73$ points and is regarded to be "satisfactory". The level which equalled to 0.74-0.89 (74-89 points) was sufficient that according to the traditional national scale is considered to be "good". The high level of phonetic competence equalled to or was higher than 0.9 (90-100 points) and was the ground for receiving the "excellent" grade.

Next stage of the experimental work itself was carried out, within its framework the experimental group was trained in using Web 2.0 tools and e-materials through mobile devices in the form of presentations, videos, text documents, links with tips and hints on English pronunciation.

At this stage future interpreters received an access to Google Disc where they could find some theoretical materials and guides as to how to work on the course of Practical Phonetics. There was also a set of requirements and criteria for successful course completion and an Event-Glide Calendar as a Guide of a Coursework. Using the given links students had an opportunity to watch some motivating videos, where they were told about main issues the phoneticians are concerned about. After watching those video fragments students were asked to split into four groups and create a group mind-map of key pronunciation problems they were going to deal with. Such kind of project work on a group mind mapping was in real-time communication. Thus, initially mobile devices were actively used in the organisation of training on introductory and adaptation module.

During English phonetic classes mobile communication tools were used for interactive communication in learning such phonetic units as "The Role of Practical Phonetics in English Language Learning", "Articulatory Mechanisms: Organs of Speech and their Work", "Articulation of English Consonants", "Articulation of English Vowels", "Articulatory Modification of Sounds in Connected Speech", "The Music of English Utterance: Intonation", "Pronunciation Practice: Vowels", "Pronunciation Practice: Consonants", "Review". Within the stage, some educational materials became available for students in mobile form (mobile didactic tests, tasks, etc.), as they were located on mobile browsers. The suggested links helped students to find video explanation of sound articulation and to see the pictures of sound articulation. Besides, students had an opportunity to drill sounds on-line. At this stage students first trained the articulation of the sounds in isolation, then they were given texts to drill articulatory modification of sounds in connected speech. Special attention was spared to teaching imitation of English intonation in various contexts. In the Appendix 1 one may see useful links which we used to form the phonetic competence of future interpreters. There students could find 39 video fragments as to how to correct pronunciation, where A. Underhill demonstrates his practical approach to teaching phonetics. The website http://clas.mq.edu.au/ speech/phonetics/index.html includes some material, elaborated by A. Gimson as to main issues of English Phonetics and Phonology.

The result of this stage was a productive one. To get a mark students had to create their own folder under the title "My pronunciation success" where they collected the records of their reading texts; drew diagrams of their test achievements, gathered data with useful pronunciation tips; created e-presentations on the role of phonetics in their life. Having finished the work, students shared the links within the group to get a peer review assessment. In our opinion, such type of work stimulated students not only to master their pronunciation but to use a creative approach to language study as well. The experiment was also devoted to the comparison of the articulation basis of the English language and the native one. We consider the issue to be of primary importance because interference is manifested at all levels of the phonological system of the languages. A student should have mastered the articulation of sounds and syllables, as well as the word stress and intonation. To do this, students should know the differences between the articulation bases of the languages, that is "the general tendencies the native speakers have in the way they move and hold their lips and the tongue both in speech and in silence".

Within the last stage of the experiment, students had to fulfil different tasks and after completing them they were given two modular tests and one examination test in a mobile format (see the Appendix 2). At the 
end of our work with the course of Practical Phonetics, we spared our time to reflection on the work done. Students were asked to write their feedbacks and attach them to the walls in the electronic classroom. Besides, we invited some experts to assess the course and share their impressions of the work done both by students and teachers.

The qualitative part of the study included a post-study questionnaire involving open-ended questions.

There were such questions as: What problems do you still have with your pronunciation? What exercises were the most difficult for you? What exercises did you like best of all and why? The data collected from the questionnaires were also compared with the previous results. This comparison allowed the researchers to verify participants' responses and increased the reliability of results.

\section{Results}

The obtained data of the experiment on the implementation of m-learning as an additional source of forming phonetic competence of future interpreters indicate the effectiveness of the teaching methods. A comparative analysis of the results revealed the positive dynamics of the levels of forming phonetic competence of the experimental group, while there were not noticed any significant changes in the control group of students. Students of the experimental group demonstrated high and average levels of cognitive, pragmatic and reflective criteria. Thus, 55.2\% of EG students showed a high level of cognitive criterion formation while there were only $11 \%$ before conducting the experiment; $33.7 \%$ of students showed average level, $11.1 \%$ - low level. The levels of the cognitive criterion formation in CG were as follows: high changed from $10.2 \%$ to $28.1 \%$, average - from $25.7 \%$, to $48.9 \%$, low - from $64.1 \%$ to $15 \%$. There were also positive changes in the pragmatic criterion: a high level $-48.9 \%$; average $-34 \%$; low level $17.1 \%$ of students. As for the reflective criterion - a high level reached $51.1 \%$ of students, $42.3 \%$ demonstrated an average level and $6.6 \%$ of students were at a low level. The results are shown in Table 2.

Table 2. The dynamics of the levels of manifestation of phonetic competence of future interpreters

\begin{tabular}{|l|c|c|c|c|c|}
\hline Criteria & Levels & \multicolumn{2}{|c|}{ Before the experiment, \% } & \multicolumn{2}{c|}{ After the experiment, \% } \\
\cline { 3 - 6 } & & $\begin{array}{l}\text { EG } \\
23 \text { people }\end{array}$ & $\begin{array}{l}\text { CG } \\
27 \text { people }\end{array}$ & $\begin{array}{l}\text { EG } \\
23 \text { people }\end{array}$ & $\begin{array}{l}\text { CG } \\
27 \text { people }\end{array}$ \\
\hline \multirow{2}{*}{$\begin{array}{l}\text { Cognitive } \\
\text { criterion }\end{array}$} & High & 11 & 10.2 & 55.2 & 28.1 \\
\cline { 2 - 6 } & Average & 27.2 & 25.7 & 33.7 & 48.9 \\
\cline { 2 - 6 } & Low & 61.8 & 64.1 & 11.1 & 23 \\
\hline \multirow{2}{*}{$\begin{array}{l}\text { Pragmatic } \\
\text { criterion }\end{array}$} & High & 14 & 12.5 & 48.9 & 15 \\
\cline { 2 - 6 } & Average & 32.2 & 29.1 & 34 & 36.8 \\
\cline { 2 - 6 } $\begin{array}{l}\text { Reflective } \\
\text { criterion }\end{array}$ & Low & 53.8 & 58.4 & 17.1 & 48.2 \\
\cline { 2 - 6 } & High & 12.2 & 10.7 & 51.1 & 13.8 \\
\cline { 2 - 6 } & Average & 26.8 & 24.9 & 42.3 & 46.9 \\
\hline
\end{tabular}

The comparative analysis of the results showed that in the group where we used m-learning as an additional means of forming phonetic competence of future interpreters the average score has increased significantly. The given above data show the increasing tendency in the phonetic competence of future specialists. The effectiveness of the experiment was confirmed by the obtained efficiency coefficients in terms of the average number of correctly performed tasks during the experiment and in terms of the standard deviation. The obtained data allow us to argue that the use of m-learning as an additional source of teaching practical phonetics of future interpreters influences positively the formation of their phonetic competence. As hypothesised, our experiment proves that the effectiveness of forming phonetic competence of future interpreters increases if this formation is carried out with the use of m-learning.

\section{Discussion}

Results of the formative experiment showed positive changes in the levels of formation of phonetic competence of the experimental group of future interpreters in comparison with the control group. From the results, it is clear that usage of m-learning increases the knowledge of terminology and ability to product and percept English speech easily. Overall, the rise of Internet technologies which one can classify as Web 2.0 technologies has generated a good deal of interest in education, thus the 21 st century scientists allege that 
Web 2.0 technologies, such as m-learning can be used in mixed or virtual classrooms, forums, or courses (Eid Hamoudeh et al., 2018). These technologies create favourable conditions for professional training and collaborative work. Moreover, such innovations as distance learning, electronic learning and mobile learning offer methods, which decrease the limitations of traditional education.

The obtained results prove that future interpreters also increase their additional skills. They are able to use such programs as Google Class, Instant Messaging, Excel, Gretl more effectively. Using m-learning tools during the course of Practical Phonetics became the platform to interact, communicate and share students' learning experiences. A similar pattern of results was obtained in the previous studies (Chin et al., 2009; Arashnia \& Shahrokhi, 2016). Researchers stated that m-learning has its own strengths and weaknesses, but its use stimulates students to improve their studying skills. Moreover, m-learning allows reducing the time for verification, correction, and preparation of phonetic tasks. It also allows the students to learn at their own pace and requirement.

Thus, among the significant advantages of this type of training students noted the availability of training materials, ease of communication and consulting, availability of high-quality mobile educational content. Teachers also noted that this format of training changes the attitude of students to their own education, allows them to develop analytical thinking, skills of self-organisation, self-development, professional development, skills of critical analysis of knowledge and effective application in practice. It is noteworthy, that mobile technologies will be particularly effective in the development of the adaptation module in the curriculum of training of disabled people and persons with disabilities.

That is why we consider applying m-learning in teaching English phonetics to be significant and an effective way of forming students' phonetic competence. In our opinion, it also influences students' desire to study that is quite important for achieving professional goals.

In future research, we will focus on the usage of m-learning for the courses of theoretical linguistic disciplines. The most promising way to introduce mobile devices in learning is a competent combination of new forms of learning (interactive lectures, webinars, simulations, trainings, discussions), new types of learning tasks (slide presentations, web projects, training podcasts) and traditional ones. M-learning in the system of professional education should be based on the principle of interactive managed self-learning, which will reduce the destructive impact of information and communication technologies on the social and cognitive activities of future interpreters. It is necessary to research the influence of it for the development of communicative competences on the whole. It is also necessary to work out electronic tutorials with selected multimedia programs for developing the educational process in teaching future interpreters English.

\section{Conclusions}

This study was primarily motivated by the need to make the pronunciation training of Ukrainian interpreters into English at Bohdan Khmelnitsky Melitopol State Pedagogical University more efficient. We have focused on the problem of forming phonetic competence of future interpreters through mobile learning as an additional educational source. The comparative analysis showed the effectiveness of the proposed methods of teaching Practical Phonetics. Thus, mobile learning in teaching English pronunciation has a high didactic potential, and its technology interning in education create a new model of training. The implementation of this model in practice is possible with the effective use of interactive, innovative teaching methods, methods based on student's autonomy.

\section{References:}

Abazi-Bexheti, L., Kadriu, A., Apostolova-Trpkovska, M., Jajaga, E., \& Abazi-Alili, H. (2018). LMS solution: evidence of Google Classroom usage in higher education. Business Systems Research, 9 (1), 31-43. https://doi.org/10.2478/bsrj-2018-0003

Arashnia, M. \& Shahrokhi, M. (2016). Mobile Assisted Language Learning: English Pronunciation among Iranian Pre-intermediate EFL Learners. Journal of Applied Linguistics and Language Research, 3(4), 49-62. Retrieved from http://www.jallr.com/index.php/JALLR/article/view/334

Bates, T. (2010). "New Challenges for Universities: Why They Must Change.” In U.-D. Ehlers and D. Schneckenberg (Eds.), Changing cultures in higher education (pp.15-27). New York: Springer International.

Bespal'ko, V.P. (2006). Parametry i kriterii diagnosticheskoi tzeli [Parametres and criteria of diagnostic goal]. Kyiv, Ukraine: Lybid'.

Bartolomé-Pina, A., García-Ruiz, R., \& Aguaded, I. (2018). Blended learning: overview and expectations. Revista Iberoamericana de Educación a Distancia, 21 (1), 33-56. https://doi.org/10.5944/ried.21.1.18842

Chin, H., Wen, S. \& Sheng, C. (2009). Apply Web 2.0 tools to constructive collaboration learning: A case study in MIS course. In Proceedings of Research, Relevance and Rigour: Coming of age: 18th Australasian Conference on Information Systems (pp. 163-171). Toowoomba, Australia: University of Southern Queensland.

Common European Framework of Reference for Languages: Learning, Teaching, Assessment (CEFR) (2011). Council of Europe. Retrieved from http://www.coe.int/t/dg4/linguistic/CADRE_EN.

Cherednychenko O. I. (2007). Pro movu i pereklad [On language and translation]. Kyiv, Ukraine: Lybid'.

Goncharova, N.L. (2006). Formirovaniye inoyazychnoy fonetiko-fonologicheskoy kompetentsii u studentov-lingvistov: na materiale angliyskogo yazyka [Forming foreign language phonetic-phonological competence of linguistic students based on the 
material of the English language]. Unpublished PhD dissertation, North Caucasus State Technical University, Stavropol, Russian Federation.

Eid Hamoudeh, A., Samsiah, A., \& Bashir, I. (2018). Technology-supported online writing: an overview of six major web 2.0 tools for collaborative-online writing. Arab World English Journal, 9 (1), 433-446. https://doi.org/10.24093/awej/vol9no1.30

Gimson A.C. (1989). An Introduction to the pronunciation of English. 4th Edition. London: Edward Arnold

Kekwaletswe, R. (2007). Knowledge transformation in a mobile learning environment: An inquiry of ubiquitous context and social presence awareness. Unpublished PhD thesis, University of Cape Town.

Kenworthy, J. (1987). Teaching English Pronunciation. London: Longman.

Khomutova, A. (2013). Formirovaniye foneticheskoi kompetenzii na osnovi multimedia [Forming of phonetic competence on the basis of multimedia]. Unpublished PhD dissertation, Tambov State University named after GR Derzhavin.

Naismith, L., Lonsdale, P., Vavoula, G., \& Sharples, M. (2004). Literature Review in Mobile Technologies and Learning. Report 11. Bristol Futurelab.

Pegrum, M. (2005). Mobile learning: languages, literacies and cultures (new language learning and teaching environments). London: Palgrave Macmillan.

Riabukha, T. V., Gurova, T.Y., Zinenko, N. V., \& Gostishcheva, N.O. (2018). Fonetychna kompetentnist maybutnih perekladachiv: rysy formuvannya [Phonetic competence of future interpreters: features of formation]. Naukovyi visnyk Melitopolskoho derzhavnoho pedahohichnoho universytetu imeni Bohdana Khmelnytskoho. Seriya: Pedahohika, 2(19), 151-156. Retrieved from http://eprints.mdpu.org.ua/id/eprint/2802/

Sharples, M. (2006). Big Issues in Mobile Learning. UK, Nottingham: Kaleidoscope Network of Excellence, Mobile Learning Initiative.

Taylor, J. (2006). Evaluating Mobile learning: What are appropriate methods for evaluating learning in mobile environments? In M. Sharples (Ed.), Big Issues in Mobile Learning. UK, Nottingham: Kaleidoscope Network of Excellence, Mobile Learning Initiative.

Zapolskykh, S. (2017). Translator's and interpreter's professional competence (case study: bachelor and master degree programs). Journal of Vasyl Stefanyk Precarpathian National University, 4(1). https://doi.org/10.15330/jpnu.4.1.186-194

Received: January 29, 2019 Accepted: April 13, 2020 


\title{
Appendix 1.
}

Pronunciation resources which can be useful when forming students' phonetic competence

1) https://www.slideshare.net/MariaMarthaManetteMadrid/the-organs-of-speech-and-their-function;

2) https://www.mimicmethod.com/ft101/place-of-articulation

3) - https://www.youtube.com/watch?v=dfoRdKuPF9I;

4) https://www.youtube.com/watch?v=u7jQ8FELbIo;

5) http://www.bbc.co.uk/learningenglish/english/features/pronunciation; pronunciation differences between $\mathrm{BE}$ and $\mathrm{AE}-$ https://www.youtube.com/watch?v=G4Z5qngn-48.

6) http://www.bbc.co.uk/voices/recordings/ introduced students to a variety of dialects, slang, taboo words, accents that can be found in the UK.

7) http://www.macmillanenglish.com/pronunciation/interactive-phonemic-charts/\#british-english; http://www.macmillanenglish.com/pronunciation/videos-with-adrian-underhill/ was very useful in our work.

Appendix 2.

A Pronunciation Questionnaire

\author{
1. How good is your English pronunciation? \\ a) Circle your answer: $1=$ low, $5=$ high. \\ vowels \\ consonants \\ word stress \\ sentence stress \\ intonation
}

\section{Note any particular problems you have with English pronunciation.}

vowels.

consonants

word stress

sentence stress.

intonation.

3. Which aspects of English pronunciation do you find most difficult?

4. How important is it for you to have good English pronunciation?

Circle your answer: $1=$ low, $5=$ high.

When you talk to your fellow students?

When you talk to your teacher?

When you talk to native speakers of English?

When you talk to other non-native speakers in English?

5. Which sounds of English are different to those in your first language?

6. Which aspects of English pronunciation do you find most difficult?

7. How dictionaries can help you with pronunciation of English words?

8. What do dictionaries use to explain pronunciation?

9. In your language, how is important information highlighted when speaking?

10. What makes a good pronunciation? 